\title{
FINANCIAL CONSTRAINTS AND EXPORT PARTICIPATION OF SMES IN POST-COMMUNIST COUNTRIES*
}

\author{
Ramiz RAHMANOV \\ (Received: 29 August 2017; revision received: 1 May 2018; \\ accepted: 1 September 2018)
}

\begin{abstract}
This paper examines the impact of medium- and short-term financial constraints on the probability of export participation of SMEs in 28 post-communist countries. The regression analysis conducted over the cross-sectional sample of SMEs taken from the BEEPS III-IV-V shows that the mediumand short-term financial constraints produce a significantly negative effect on the probability of exporting. Although there exist arguments for why the effects of medium- and short-term financial constraints can differ from each other, both the medium- and short-term financial constraints appear to reduce the probability of exporting equally by $25 \%$. The regression results also suggest that more productive, innovative, and larger SMEs, and also SMEs with international quality certificates are more likely to export. When the regressions are separately estimated for the first-time and continuous exporters, it appears that only the probability of exporting of continuous exporters is significantly sensitive to the financial constraints. Furthermore, the regressions separately run for the direct and indirect exporters show that the financial constraints have a larger effect on the probability of exporting of indirect exporters. The heterogeneity analysis shows that there is a significant heterogeneity in the effects of medium- and short-term financial constraints on the likelihood of exporting across regions, industries, periods, and firm types.
\end{abstract}

Keywords: financial constraints, exports, export participation, SMEs, post-communist countries

JEL classification indices: F10, G20

* I would like to thank two anonymous referees for comments and suggestions which helped me improve the paper. Furthermore, I would like to thank Sergey Stepanov and Irina Ivashkovskaya (National Research University Higher School of Economics, HSE), and other participants of the session on "Financial conditions for business development" of XVIII International Academic Conference on Economic and Social Development (Moscow) for useful comments and recommendations.

Ramiz Rahmanov, Head of the Modelling and Forecasting Division at the Central Bank of the Republic of Azerbaijan. E-mail: rahmanovrr@gmail.com 


\section{INTRODUCTION}

Foreign market entry incurs high sunk costs because before starting exporting, firms need to conduct marketing research, increase the stock of capital, adapt products to local tastes, organise and maintain distribution networks, and make advertising campaigns. Along with high entry costs, firms also incur higher variable costs as they additionally have to pay for cross-border transportation, duties, freight insurance, and trade credit insurance (e.g. Melitz 2003; Manova 2012; Manova et al. 2015). Furthermore, as delivery of products to foreign consumers takes much more time than delivery of products to domestic consumers, firms receive payments for exported products much later than for products sold internally (e.g. Melitz 2003; Manova 2012). This, in turn, demands from exporters to store larger inventories relative to firms serving only domestic markets. Firms can finance entry costs and greater working capital needs either through retained earnings or loans. Small and medium-sized enterprises (SMEs) tend to have modest retained earnings which are unlikely to be enough to fund sunk and other related costs; therefore, to export their products and/or services, SMEs need to borrow from banks. The ease with which SMEs can access external finance can predetermine their decision to export or not.

Although the prediction of the negative effects of financial constraints on the probability of exporting seems obvious, the literature provides mixed evidence. For example, Bellone et al. (2010), Berman - Héricourt (2011), Abort et al. (2014), Nagaraj (2014), and Fauceglia (2015) find statistically significant negative relationship between financial constraints and export participation, while Greenaway et al. (2007), Stiebale (2011), and Jinjarak - Wignaraya (2016) do not confirm this relationship. The heterogeneity in the opinions seems to support the prediction of Chaney (2016) that the significance and magnitude of the effects of financial constraints on export participation depends on the productivity and liquidity distributions of firms.

This paper aims to investigate the impact of financial constraints on the probability of exporting of SMEs in the post-communist countries using firm-level data taken from the last three rounds of the Business Environment and Enterprise Performance Survey (BEEPS). I differentiate between medium- and short-term financial constraints as there exist reasons to believe that they produce effects of different magnitudes on the probability of exporting. The medium-term financial constraints are more likely to have a larger effect on the probability of exporting than the short-term financial constraints as the main cost of foreign market entry is sunk costs which represent large amount and cannot be recovered in the short-term. The short-term financing which usually does not involve large amounts can be used to meet increased working capital needs due to production 
expansion as firms will be able to return borrowed funds shortly after selling their products or services. The focus on SMEs from the post-communist countries was not accidental. As the post-communist period is characterised by export growth, emergence of new enterprises and expansion of financial intermediation, these countries represent a very interesting setting for testing the effects of financial constraints on the probability of foreign market entry. Additionally, the post-communist countries are quite different in terms of export performance of their SMEs and financial development and therefore provide sufficient amount of variation necessary for good analysis. As such, this paper not only provides new microeconomic evidence to scarce literature on the effects of financial constraints on the likelihood of exporting but also improves our understanding of the relationship between financial constraints and the probability of exporting in the emerging and developing economies.

The cross-section analysis shows that the medium- and short-term financial constraints have a significantly negative influence on the likelihood of exporting. The lack of access either to the medium- or short-term financing reduces the probability of exporting by $25 \%$. Thus, there is no empirical evidence to support the proposition that the medium- and short-term financial constraints produce the effects of different magnitudes. The explanation for this finding can be that despite the maturity considerations, SMEs equally treat both medium- and shortterm financing, probably by reason of easier accessibility of the latter. The regression results also show that more productive, innovative, and larger SMEs, and also SMEs with international quality certificates are more likely to export. Furthermore, the results from the separate regressions for the first-time and continuous exporters provide evidence that the medium- and short-term financial constraints have a significantly negative effect only on the likelihood of exporting of the continuous exporters. The magnitudes of both the medium- and short-term financial constraints are equal. The separate regressions are also run for the direct and indirect exporters to test whether the results vary across export modes. The regression output indicates that the medium- and short-term financial constraints produce a significantly larger negative effect on the probability of exporting of the indirect exporters than on the direct exporters. For the direct exporters, both the medium- and short-term financial constraints have influences of the same magnitude, while for the indirect exporters, the short-term financial constraints cause a larger effect than the medium-term financial constraints.

Additionally, the heterogeneity analysis is conducted to find whether the results differ across country groups, industries, periods, and firm types. Such broad heterogeneity analysis enhances our comprehension of the relationship between financial constraints and likelihood of exporting. It is found that the medium- and short-term financial constraints have a larger and more significant effect on the 
probability of exporting for SMEs from the new European Union (EU) member states. However, the magnitudes of both types of constraints are the same. Further, contrary to the expectation, the financial constraints appear to be binding for exporting of SMEs mainly from the low sunk cost industries. And compared to the medium-term financial constraints, the short-term constraints tend to have a larger influence. The analysis also reveals that the financial constraints, especially the short-term ones, are more critical for SMEs interviewed in the period of financial crisis. Finally, it is found that the short-term financial constraints have a larger effect on the probability of exporting of low productivity, innovative, small, and domestic SMEs than the medium-term financial constraints.

The rest of the paper is organized as follows. The next section reviews the related literature. Sections 3 and 4 present the theoretical background and the methodology of the research. Section 5 describes the data and reports the results. Finally, Section 6 concludes and provides policy implications.

\section{LITERATURE REVIEW}

The pioneering study which generated a series of papers analysing the link between financial constraints and firm export behaviour was conducted by Melitz (2003), who introduced the sunk market entry costs to the trade model and showed that the existence of such costs leads to the fact that only high productive firms gain from export participation and therefore enter foreign markets. Chaney (2016) extended the Melitz model by adding financial constraints. His model predicts that financial constraints are important factors influencing firms' exporting decisions because firms that are willing to enter foreign markets need to have enough liquidity to cover the related sunk costs. Potentially, only efficient firms can generate liquidity sufficient to meet the sunken export costs. However, in real life, the significant part of firms including very efficient entities need access to external capital as they are unable to fund large sunk market entry costs through retained earnings or capital flows (Manova et al. 2015). Therefore, for a large group of firms, foreign market entry decisions are predetermined by their access to external finance which depends on development of financial institutions and idiosyncratic characteristics of firms (Manova 2012).

A few firm-level studies have already examined the impact of financial constraints on the likelihood of exporting both for advanced and developing countries. One of the first empirical studies which directly examined the relationship between financial constraints and exporting decisions of firms was conducted by Greenaway et al. (2007). For the analysis, the authors used a panel of 9,292 
UK manufacturing firms for the period of 1993-2003. They conclude that although the ex-ante good financial health has no statistically significant effect on the probability of exporting, export participation tends to have a positive effect on ex-post financial health. Furthermore, the authors find that the relationship between financial health and export participation is significant for the continuous exporters but not for the first-time exporters. Bellone et al. (2010) analyze the effect of financial constraints on export behaviour using an unbalanced panel of more than 25,000 French manufacturing firms for the period of 1993-2005. In contrast to Greenaway et al. (2007), the authors find a strong negative relationship between financial constraints and likelihood of exporting but fail to find evidence that export participation leads to the improvement of financial health of firms. In particular, they conclude that the availability of financing accelerates foreign market entry of the first-time exporters. Stiebale (2011) also examines the link between financial constraints and foreign market participation employing the French data but uses a different database. Conducting empirical analysis over 200,000 firm-year observations for the period of 1998-2008, the author finds no strong evidence for the existence of any relationship between financial constraints and probability of exporting. The author also finds that financial factors have no significant influence on either first-time or continuous exporters' decisions to export. Furthermore, Stiebale investigates the influence of capitalintensity of industries on the strength of the link between financial constraints and export participation and finds that the financial constraints produce no influence regardless of the capital and technology intensities, scale of sunk costs, and productivity levels. Minetti - Zhu (2011) examine the effect of credit constraints on the export participation and volume of exports using a sample of the Italian firms. The authors conclude that credit rationed firms are less likely to export and their export volumes are lower than those of the non-rationed entities. Additionally, they find that the effect of strong rationing on export participation is larger for old, big, and high growth SMEs and SMEs from high external dependent and high-tech industries than for young, small, and low growth SMEs and SMEs from low external finance dependent and low-tech industries, respectively.

Berman - Héricourt (2011) use an unbalanced panel of 5,000 firms over the period of 1998-2004 to study the impact of financial constraints on export behaviour in 9 developing and emerging markets. The authors find that an improvement of financial health of firms significantly increases the probability of exporting but has no significant effect on export volumes. Further, the authors conclude that the financial constraints exert a significantly larger effect on export participation of the first-time exporters than the continuous exporters. Berman - Héricourt also consider the impact of financial development on the strength of the relation- 
ship between the financial constraints and export participation. They find that the low level of financial development is associated with the smaller effect of financial factors on the probability of exporting. Abor et al. (2014) study the impact of SMEs' access to bank finance on the probability of exporting in Ghana. They find that SMEs with better access to bank finance are more likely to export. Nagaraj (2014) analyses the relationship between likelihood of exporting and financial constraints using data on the Indian firms. He concludes that financial constraints negatively affect the probability of exporting but have no effect on the extent of exports. Fauceglia (2015) investigates the impact of financial constraints on the probability of exporting using firm-level data of 17 developing economies. The author finds a positive relationship between firm's liquidity and likelihood of exporting and, in contrast to Berman - Héricourt (2011), Fauceglia concludes that the relationship is stronger in countries with weaker financial development.

Conceptually, this paper relates to the study of Jinjarak - Wignaraya (2016) who examine the impact of the availability of overdraft facilities and term loans on foreign market participation of SMEs in the emerging markets of Asia and Latin America. Overdraft facilities basically represent short-term financing, and term loans reflect medium-term financing. They find that the availability of the overdraft facilities increases the probability of exporting and the share of exports in total sales, while the use of term loans produces no significant effect. My paper extends the existing research at several levels. First, in contrast to Jinjarak Wignaraya (2016), it uses a more precise proxy for the short-term financial constraints as the non-use of the overdraft facilities can be driven not only by the failure to obtain such facilities but also by the non-necessity of short-term financing. Second, as an extension to the previous study, I run separate regression analysis for the sub-samples of direct and indirect exporters to examine whether the results vary by export mode. There exists a good reason to expect that the financial constraints produce a larger effect on the probability of direct exporting because this mode involves higher entry-sunk costs than indirect exporting. Finally, I conduct a broad heterogeneity analysis of the effects of financial constraints on the probability of exporting to determine whether the effects differ across regions, industries, periods, productivity levels, sizes, innovation statuses, age groups, and ownership categories.

\section{THEORETICAL BACKGROUND}

Firms governed by the desire to preserve their autonomy usually prefer to use internal financial resources to finance investments and operations (Öhman Yazdanfar 2017), and only if internal financing is insufficient, firms use external 
financial resources which can be in the form of loans of different maturities. ${ }^{1}$ However, the use of external financing by SMEs can be difficult due to the agency problems, such as moral hazard and adverse selection which usually emerge in contractual relationships between creditors and SMEs due to information asymmetry (Chittenden et al. 1996; Michaelas et al. 1999). Dealing with the agency problems by means of monitoring and bonding can be costlier to SMEs. For example, monitoring could be problematic because the legislation usually does not require SMEs to disclose detailed information on their performance, so they will need to bear significant costs for collection of such information for creditors at least in the beginning. Bonding methods, e.g. incentive schemes, also could be difficult to apply to SMEs. Apart from the agency problems, lower profit margins due to stronger competition and higher market fragmentation in which SMEs traditionally operate increase risks to creditors and reduce their willingness to lend (Esperança et al. 2003). As a solution to all these problems, SMEs can use collateral and/or agree on high lending rates; however, many SMEs cannot provide sufficient collateral to raise the necessary amount of financing and/or afford very high interest rates and thereby remain financially constrained.

The presence of financial constraints is expected to decrease the probability of foreign market entry as it limits the ability of firms to undertake necessary investments to begin and maintain exporting (e.g. Melitz 2003; Manova 2012). However, it is reasonable to assume that the magnitudes of the effects of medium-term financial constraints would differ from those of the short-term financial constraints for the following reasons. Before entering foreign markets, firms incur certain sunk costs which, as a rule, cannot be recovered in the short period, so to finance the sunk costs; firms need to attract medium-term finance (Capiro - Demirguc-Kent 1998). Short-term finance, in turn, is needed to increase the flexibility of firms to changes in foreign demand and payment delays through quick provision of financial resources needed to purchase working capital for production of export goods and services (Capiro - Demirguc-Kent 1998; Jinjarak - Wignaraja 2016). As in contrast to the amount required to satisfy the growing working capital needs, the sunk costs usually represent significantly larger amount and have greater importance, one can anticipate that the magnitude and significance levels of the medium-term financial constraints will be larger.

Although the matching principle urges that the debt maturities should correspond to the maturities of the financed assets, in practice, SMEs widely use short-term financing as a source for capital investments (Viscione 1986). Such

I do not consider external equity as a viable financing option for SMEs because, first, it is not beneficial to issue equity for relatively small amounts, and second, SMEs need to offer equity at a considerable discount to make it attractive for investors (De Maeseneire - Claeys 2012). 
a choice by SMEs can be explained by lower interest rates and relatively easy procedures of obtaining short-term credits compared to long-term ones (GarciaTeruel - Martinez-Solano 2007). Lenders, in turn, prefer to give short-term credits to smaller firms at lower interest rates and under more relaxed requirements as the short maturity allows them to control borrowers more strictly (Capiro Demirguc-Kent 1998). In particular, a lender can terminate rolling over credit if a project becomes unprofitable or change interest rates in the next roll as new financial information on project performance appears. Given the prevalence of short-term financing, one can expect that for SMEs, the short-term financial constraints can have larger effects on the probability of export participation than the medium-term constraints. Therefore, whether the magnitude and significance levels of the medium-term financial constraints are larger than those of the shortterm constraints is ultimately an empirical question.

\section{METHODOLOGY}

The export probability of SMEs is modelled as a linear function of financial constraints faced by firms and other control variables which also potentially affect the likelihood of exporting:

$$
P\left(\exp _{i}=1 \mid x\right)=\alpha_{0}+\text { constraints }_{i}+\text { controls }_{i}+\varepsilon_{i},
$$

where constaints s $_{i}$ represent either medium- or short-term financial constraints. Controls $_{i}$ is a set of control variables which includes labour productivity, firm size, availability of quality certificates, firm age, human capital, innovation, foreign ownership, ethnicity, language, and religion fragmentation, country, industry, and year dummies, and $\varepsilon_{i}$ is the error term. To estimate the model, I use the Ordinary Least Squares (OLS) estimator.

Following the theoretical discussion, I expect that both medium- and shortterm financial constraints reduce the probability of exporting. However, which constraint has a larger effect on the probability of foreign market entry is a question. The control variables are supposed to account for the firm-specific factors which can have effects both on the likelihood of exporting and financial status of a SME. Thus, more productive firms are more likely to be successful in the foreign markets; therefore, credit institutions are inclined to lend to such firms as there is higher probability that these firms will pay back loans ( $\mathrm{Li}$ - Yu 2009). Larger firms are more likely to export and tend to be less financially constrained than smaller ones because in contrast to small firms, large firms usually have greater production, marketing, $\mathrm{R} \& \mathrm{D}$, and management capacity to succeed in 
foreign markets and have sufficient assets to pledge as collateral for bank loans (Nagaraj 2014).

The probability of exporting and securing a bank loan can also depend on firm age. Young firms have less marketing and management experiences, so for them, it will be risky to enter foreign markets. Young firms also have a short record of history, so for banks, it becomes more difficult to assess the potential of young borrowers to generate return necessary to repay loans. In such situations, banks can prefer to ration young firms (Verani - Gross 2012). Furthermore, the likelihood that firms gain a market share abroad depends on the quality of the products. So, lenders are more willing to offer loans to firms that are capable of producing good quality products. Human capital is also an important factor affecting the probability of success since firms with qualified employees are more likely to make optimal decisions and be successful; therefore, creditors are more inclined to lend to firms with high human capital. Firms with foreign ownership are more likely to export and obtain loans from banks as they can benefit from advanced technology, managerial expertise, business reputation, and financial guarantees of foreign owners (Nagaraj 2014). Finally, ethnicity, language, and religion fragmentation, country and industry dummies are supposed to account for other comparative advantages which certain countries and industries can lay out for exporters, while year dummies are assumed to control for period specific circumstances which affect all SMEs regardless of the country of origin and the industry of operation.

The main issues which can challenge estimation results include an inappropriate choice of model, endogeneity, and reverse causality. The linear probability model can take values outside the $0-1$ interval; therefore, for the robustness check purposes, I use a probit model to estimate the relationship. The probit model, which is estimated using the maximum likelihood (ML) estimator, imposes restrictions on the relationship between the export probability and explanatory variables so that the probabilities lie inside the $0-1$ interval. The regression includes a rich set of control variables; however, there is still a risk that some factors, which affect both export probability and financial status of SMEs, are omitted from the regression analysis and therefore the results may be biased. It can also be the case that the financial status does not affect the likelihood of exporting, but an export status influences financial circumstances of a SME. Furthermore, the regression includes a labour productivity variable which is usually an endogenous factor. To check the robustness of the results to endogeneity and reverse causality, I use the two-stage least square (2SLS) estimator. As the instrument for the financial variables, I use the economic sector - country - region's average perception of firms about the obstacles created by the access to finance, and as the instrument for productivity, I use past productivity with three-year lag. 


\subsection{Data description}

The data come from the third, fourth, and fifth rounds of the BEEPS conducted by the EBRD together with the World Bank in 28 countries of Eastern Europe and Central Asia in the years of 2005, 2008-2009, and 2012-2014, respectively. This is a firm-level survey based on face-to-face interviews with managers. The objective of the survey was to assess the quality of the business environment in the region. Although the survey was conducted periodically, the structure of the sample was cross-sectional as the number of firms which participated at least in two rounds was very small. The non-panel structure of the sample does not allow controlling for unobserved heterogeneity and dynamics in the relationships. To address these shortcomings, I employ a good set of controls to account for the firm-specific factors and include period dummies to account for the time factors. The sample includes observations for 33,523 firms, of which 27,235 are SMEs. Following a conventional definition, a firm is considered to be a SME if the number of its employees does not exceed 99 people. However, in the regression analysis, I use a sample of only 16,652 SMEs as not all surveyed firms reported all the necessary information.

The survey asks respondents to provide information about the share of national sales as a percentage of total sales. The response to this question allows determining whether a firm is an exporter or not. The survey results of three rounds, which are summarized in Table 1, show that in the post-communist countries, during 2005-2014, the share of exporters declined from $20 \%$ to $15 \%$. However, when the data are disaggregated by regions, the picture changes completely. The disaggregated data show that in fact, only the shares of exporters in the Caucasian and European parts of the Commonwealth of Independent States (CIS) have a negative trend (Table 1). In the new EU member states, the share of exporters instead demonstrates a positive trend, while in the Balkans and Central Asia, the share of exporters has a mixed pattern.

Furthermore, the survey contains a set of questions which enable to identify whether a firm is financially constrained or not in the medium term. The first question asks if a firm applied for any term loan in the last year. If a respondent gives a negative answer, an interviewer asks to tell a reason of non-applying. If a respondent replies that he did not apply because he had sufficient capital, a firm is not considered to be financially constrained. But if a respondent says that he did not apply because he did not have enough collateral or interest rates were high or the application procedure was complex, a firm is considered to be financially constrained. In case a respondent says that he applied for credit, an interviewer asks about the result of the application. A firm is considered as financially constrained if the application was rejected, and vice versa. Following this procedure 
Table 1. Exports and financial constraints in the post-communist countries, \%

\begin{tabular}{|c|c|c|c|c|}
\hline Region & Indicator & BEEPS III & BEEPS IV & BEEPS V \\
\hline \multirow[t]{3}{*}{ All } & Share of exporters & 20 & 18 & 15 \\
\hline & $\begin{array}{l}\text { Share of firms financially } \\
\text { constrained in the medium-term }\end{array}$ & 27 & 30 & 32 \\
\hline & $\begin{array}{l}\text { Share of firms financially } \\
\text { constrained in the short-term }\end{array}$ & . & 22 & 26 \\
\hline \multirow[t]{3}{*}{ Balkans } & Share of exporters & 29 & 31 & 24 \\
\hline & $\begin{array}{l}\text { Share of firms financially } \\
\text { constrained in the medium-term }\end{array}$ & 25 & 28 & 27 \\
\hline & $\begin{array}{l}\text { Share of firms financially } \\
\text { constrained in the short-term }\end{array}$ & . & 17 & 15 \\
\hline \multirow[t]{3}{*}{ CIS-Caucasus } & Share of exporters & 13 & 8 & 4 \\
\hline & $\begin{array}{l}\text { Share of firms financially } \\
\text { constrained in the medium-term }\end{array}$ & 30 & 30 & 29 \\
\hline & $\begin{array}{l}\text { Share of firms financially } \\
\text { constrained in the short-term }\end{array}$ & . & 25 & 26 \\
\hline \multirow[t]{3}{*}{ CIS-Central Asia } & Share of exporters & 10 & 6 & 7 \\
\hline & $\begin{array}{l}\text { Share of firms financially } \\
\text { constrained in the medium-term }\end{array}$ & 32 & 37 & 31 \\
\hline & $\begin{array}{l}\text { Share of firms financially } \\
\text { constrained in the short-term }\end{array}$ & . & 31 & 28 \\
\hline \multirow[t]{3}{*}{ CIS-Europe } & Share of exporters & 15 & 12 & 9 \\
\hline & $\begin{array}{l}\text { Share of firms financially } \\
\text { constrained in the medium-term }\end{array}$ & 34 & 36 & 39 \\
\hline & $\begin{array}{l}\text { Share of firms financially } \\
\text { constrained in the short-term }\end{array}$ & . & 26 & 34 \\
\hline \multirow[t]{3}{*}{ New EU members } & Share of exporters & 23 & 27 & 29 \\
\hline & $\begin{array}{l}\text { Share of firms financially } \\
\text { constrained in the medium-term }\end{array}$ & 22 & 21 & 20 \\
\hline & $\begin{array}{l}\text { Share of firms financially } \\
\text { constrained in the short-term }\end{array}$ & $\cdot$ & 14 & 14 \\
\hline
\end{tabular}

Note: Balkans: Albania, Bosnia, FYROM, Montenegro, Serbia; CIS-Caucasus: Azerbaijan, Armenia, Georgia; CIS-Central Asia: Kazakhstan, Kyrgyz Republic, Mongolia, Tajikistan, Uzbekistan; CIS-Europe: Belarus, Moldova, Russia, Ukraine; New EU members: Bulgaria, Croatia, Czech Republic, Estonia, Hungary, Latvia, Lithuania, Poland, Romania, Slovakia, Slovenia.

for the identification of financially constrained firms, I find that on average, the share of medium-term financially constrained firms has increased from $27 \%$ in the third round to $32 \%$ in the fifth round (Table 1). The disaggregation of the medium-term financial constraint data by region shows that in fact, the access of firms to financial resources worsened only in the European part of CIS. In the Caucasus and the new EU member states, in contrast, the share of medium-term financially constrained firms declined. In the Balkans and Central Asia, the share of medium-term financial constrained firms showed a mixed pattern. 
Starting from the fourth round of the BEEPS, the data on the availability of overdraft facilities, which can be used in the construction of the short-term financial constraint variable, have been collected. Although the overdraft facilities represent a short-term financing instrument, the presence or absence of overdraft facilities cannot be a reliable indicator of the short-term financial constraints as it can be either supply or demand driven. Given that for firms, it is usually more difficult to receive long-term financing than short-term financing due to higher requirements to borrowers (Garcia-Teruel - Martinez-Solano 2007), one can expect that if a firm has managed to obtain a medium-term credit, it can also secure a short-term credit if necessary. Therefore, I assume that a firm which has sufficient capital or managed to secure medium-term financing or has an overdraft facility is not considered to be short-term constrained. In all other cases, a firm is considered to be short-term constrained. The statistics shows that in the fifth round relative to the fourth round, the share of the short-term financially constrained firms increased from $22 \%$ to $26 \%$ (Table 1). The disaggregated statistics shows that the shares of short-term financially constrained firms increased only in the Caucasus and the European parts of CIS. In the Balkans and Central Asia, the shares instead declined, and in the new EU member states, it remained unchanged.

Along with the financial constraints, other factors such as labour productivity, size, age, human capital, availability of internationally-recognized quality certification, innovation, and ownership can affect the likelihood of exporting. Therefore, in the regression analysis, I use a set of control variables to account for these factors (Table 2). Finally, in addition, I use a perception of access to finance as an obstacle to business to instrument endogenous finance variables and labour productivity three years ago to instrument productivity. All monetary variables are converted from the local currencies to the US dollar when necessary and transformed into real terms using US consumer price index.

Table 3 provides information on means of the financial constraint and control variables disaggregated by export status and presents results of the t-tests on the equality of means between exporters and non-exporters. Exporters are found to be less financially constrained both in the medium- and short-term. Exporters also tend to be larger, older, more productive and innovative than non-exporters. Furthermore, exporters are more likely to have internationally-recognized quality certification than non-exporters. However, interestingly, in this sample, exporters tend to have less educated employees than non-exporters. Regarding the perception of financial obstacles, the t-test shows that the difference between exporters and non-exporters is statistically insignificant. 
Table 2. Definition of variables

\begin{tabular}{|c|c|c|}
\hline Variable & Description & Source \\
\hline Export participation & $\begin{array}{l}1 \text { if the share of domestic sales is less than } 100 \%, 0 \\
\text { otherwise }\end{array}$ & BEEPS \\
\hline $\begin{array}{l}\text { Medium-term financial } \\
\text { constraints }\end{array}$ & $\begin{array}{l}1 \text { if a SME is financially constrained in the medium } \\
\text { term, } 0 \text { otherwise }\end{array}$ & BEEPS \\
\hline $\begin{array}{l}\text { Short-term financial } \\
\text { constraints }\end{array}$ & $\begin{array}{l}1 \text { if a SME is financially constrained in the short } \\
\text { term, } 0 \text { otherwise }\end{array}$ & BEEPS \\
\hline Employment & Number of permanent, full-time employees & BEEPS \\
\hline Labour productivity & $\begin{array}{l}\text { The ratio of sales to employment, US\$ } 1000 \text { per } \\
\text { employee }\end{array}$ & BEEPS \\
\hline Quality certificate & $\begin{array}{l}1 \text { if a SME has an internationally-recognised quality } \\
\text { certification, } 0 \text { otherwise }\end{array}$ & BEEPS \\
\hline Age & Firm age, years & BEEPS \\
\hline Human capital & $\begin{array}{l}\text { Percentage of the employees who have a university } \\
\text { degree }\end{array}$ & BEEPS \\
\hline Innovation & $\begin{array}{l}1 \text { if a SME introduced new products or services in } \\
\text { the last three years, } 0 \text { otherwise }\end{array}$ & BEEPS \\
\hline Ethnicity & $\begin{array}{l}\text { Measure of ethnic fractionalisation, which shows } \\
\text { the probability that two randomly chosen persons } \\
\text { belong to different ethnic groups }\end{array}$ & $\begin{array}{l}\text { Alesina et al. } \\
\text { (2003) }\end{array}$ \\
\hline Language & $\begin{array}{l}\text { Measure of language fractionalisation, which shows } \\
\text { the probability that two randomly chosen persons } \\
\text { speak different languages }\end{array}$ & $\begin{array}{l}\text { Alesina et al. } \\
\quad(2003)\end{array}$ \\
\hline Religion & $\begin{array}{l}\text { Measure of religious fractionalisation, which shows } \\
\text { the probability that two randomly chosen persons } \\
\text { belong to different religions }\end{array}$ & $\begin{array}{l}\text { Alesina et al } \\
\quad(2003)\end{array}$ \\
\hline Financial obstacle & $\begin{array}{l}0 \text { if access to finance (it reflects availability and } \\
\text { cost, interest rates, fees and collateral require- } \\
\text { ments) is not an obstacle, } 1 \text { if access to finance is a } \\
\text { minor obstacle, } 2 \text { if access to finance is a moderate } \\
\text { obstacle, } 3 \text { if access to finance is a major obstacle, } \\
\text { and } 4 \text { if access to finance is a severe obstacle to the } \\
\text { current business operations }\end{array}$ & BEEPS \\
\hline Exchange rate & $\begin{array}{l}\text { Official exchange rate (LCU per US\$, period aver- } \\
\text { age) }\end{array}$ & World Bank \\
\hline CPI of US & Consumer price index $(2010=100)$ & World Bank \\
\hline
\end{tabular}


Table 3. Descriptive statistics

\begin{tabular}{lrrrrrrr}
\hline \multirow{2}{*}{ Variable } & \multicolumn{2}{c}{ Total } & \multicolumn{2}{c}{ Non-exporter } & \multicolumn{2}{c}{ Exporter } & t-test \\
& $\mathrm{N}$ & Mean & $\mathrm{N}$ & Mean & $\mathrm{N}$ & Mean & Statistics \\
\hline $\begin{array}{l}\text { Medium-term financial } \\
\text { constraints }\end{array}$ & 15600 & 0.30 & 12812 & 0.32 & 2788 & 0.23 & $9.09^{* * *}$ \\
$\begin{array}{l}\text { Short-term financial } \\
\text { constraints }\end{array}$ & 12324 & 0.24 & 10198 & 0.26 & 2126 & 0.16 & $9.96^{* * *}$ \\
Employment & 15600 & 22.19 & 12812 & 20.46 & 2788 & 30.13 & $-22.20^{* * *}$ \\
Labour productivity & 15600 & 0.16 & 12812 & 0.11 & 2788 & 0.42 & $-2.38^{* *}$ \\
Quality certificate & 15600 & 0.15 & 12812 & 0.12 & 2788 & 0.31 & $-26.19^{* * *}$ \\
Age & 15600 & 12.00 & 12812 & 11.62 & 2788 & 13.75 & $-9.63^{* * *}$ \\
Human capital & 15600 & 30.99 & 12812 & 31.64 & 2788 & 27.97 & $5.80^{* * *}$ \\
Innovation & 15600 & 0.33 & 12812 & 0.30 & 2788 & 0.48 & $-18.27^{* * *}$ \\
Foreign ownership & 15600 & 5.00 & 12812 & 3.38 & 2788 & 12.45 & $-22.00^{* * *}$ \\
Financial obstacle & 15207 & 1.38 & 12475 & 1.38 & 2732 & 1.38 & 0.04 \\
\hline
\end{tabular}

Note: ${ }^{*} \mathrm{p}<0.1,{ }^{* *} \mathrm{p}<0.05,{ }^{* * *} \mathrm{p}<0.01$.

\subsection{Empirical analysis}

Baseline results

Table 4 reports the results of the regression analysis conducted to examine the impact of medium-term financial constraints on the likelihood of exporting of SMEs in the post-communist countries. The reported t-statistics is robust to heteroscedasticity. The first column shows the OLS estimates for the bivariate relationship between the medium-term financial constraints and probability of exporting by SMEs. The coefficient of the medium-term financial constraint variable is negative and significant at the 5\% level. Quantitatively, the magnitude of the coefficient implies that a medium-term financially constrained SME is 6\% less likely to export than a medium-term financially non-constrained SME. However, these estimation results might be biased due to omission of important controls which can affect not only the likelihood of exporting but also the financial situation of SMEs. Therefore, to address this shortcoming, I add firm-level characteristics such as labour productivity, size, quality certificate, age, human capital, innovation activity, and foreign ownership into the next regression. Column 2, Table 4 reports the results of the augmented regression. The coefficient of the medium-term financial constraint variable remains negative and significant, albeit its absolute value decreases from 0.06 to 0.02 . The coefficients of the controls are also of significant interest. All of them are statistically significant at the $1 \%$ level. For example, they show that more productive, larger, and older SMEs are more likely to export than less productive, smaller and younger SMEs. Further- 
Table 4. Medium-term financial constraints and export participation (Dependent variable: $\operatorname{Pr}[$ export participation $=1]$ )

\begin{tabular}{|c|c|c|c|c|c|c|}
\hline & (1) & $(2)$ & (3) & (4) & (5) & (6) \\
\hline & LPM & LPM & LPM & LPM & Probit & LPM \\
\hline & OLS & OLS & OLS & OLS & ML & 2SLS \\
\hline \multirow[t]{2}{*}{$\begin{array}{l}\text { Medium-term financial } \\
\text { constraints }\end{array}$} & $-0.06 * * *$ & $-0.02 * * *$ & 0.00 & $-0.02 * * *$ & $-0.02 * * *$ & $-0.25 * * *$ \\
\hline & $(-9.63)$ & $(-3.15)$ & $(-0.25)$ & $(-2.76)$ & $(-2.64)$ & $(-3.62)$ \\
\hline \multirow[t]{2}{*}{ Log(productivity) } & - & $0.03 * * *$ & $0.02 * * *$ & $0.04 * * *$ & $0.04 * * *$ & $0.03 * * *$ \\
\hline & & $(15.29)$ & $(6.59)$ & $(17.22)$ & $(17.44)$ & $(6.93)$ \\
\hline \multirow[t]{2}{*}{ Log(employment) } & - & $0.04 * * *$ & $0.06 * * *$ & $0.04 * * *$ & $0.04 * * *$ & $0.03 * * *$ \\
\hline & & $(13.43)$ & $(17.57)$ & $(13.65)$ & $(14.17)$ & $(5.08)$ \\
\hline \multirow[t]{2}{*}{ Quality certificate } & - & $0.14 * * *$ & $0.10 * * *$ & $0.11^{* * *}$ & $0.08 * * *$ & $0.11 * * *$ \\
\hline & & $(14.07)$ & (10.59) & (11.69) & (11.33) & $(9.20)$ \\
\hline \multirow[t]{2}{*}{ Log(age) } & - & $0.03 * * *$ & 0.00 & $0.02 * * *$ & $0.02 * * *$ & $0.02 * * *$ \\
\hline & & $(8.38)$ & $(0.85)$ & $(4.54)$ & $(4.61)$ & $(4.56)$ \\
\hline \multirow[t]{2}{*}{ Human capital } & - & $-0.00 * * *$ & $0.00 * * *$ & 0.00 & 0.00 & 0.00 \\
\hline & & $(-4.49)$ & $(8.07)$ & $(0.74)$ & (1.59) & $(1.24)$ \\
\hline \multirow[t]{2}{*}{ Innovation } & - & $0.08^{* * *}$ & $0.06^{* * *}$ & $0.06^{* * *}$ & $0.06^{* * *}$ & $0.06^{* * *}$ \\
\hline & & (11.78) & $(8.57)$ & $(9.61)$ & $(10.24)$ & $(8.06)$ \\
\hline \multirow[t]{2}{*}{ Foreign ownership } & - & $0.00 * * *$ & $0.00^{* * *}$ & $0.00 * * *$ & $0.00 * * *$ & $0.00^{* * *}$ \\
\hline & & (13.19) & $(10.42)$ & $(11.02)$ & (10.69) & $(9.15)$ \\
\hline \multirow[t]{2}{*}{ Ethnicity } & - & - & - & $0.15^{* * *}$ & $0.11^{* * *}$ & $0.16^{* * *}$ \\
\hline & & & & $(4.11)$ & (3.98) & (3.99) \\
\hline \multirow[t]{2}{*}{ Language } & - & - & - & $-0.14 * * *$ & $-0.11^{* * *}$ & $-0.13^{* * *}$ \\
\hline & & & & $(-4.22)$ & $(-3.97)$ & $(-3.33)$ \\
\hline \multirow[t]{2}{*}{ Religion } & - & - & - & $0.07 * * *$ & $0.08 * * *$ & $0.08^{* * *}$ \\
\hline & & & & $(3.48)$ & $(4.04)$ & $(3.28)$ \\
\hline \multirow[t]{2}{*}{ Constant } & $0.20 * * *$ & $0.06 * * *$ & $0.18^{* * *}$ & $0.25 * * *$ & - & $0.33^{* * *}$ \\
\hline & $(51.73)$ & $(4.50)$ & $(6.18)$ & $(10.46)$ & & $(9.85)$ \\
\hline Country dummies & No & No & Yes & No & No & No \\
\hline Industry dummies & No & No & Yes & Yes & Yes & Yes \\
\hline Year dummies & No & No & Yes & Yes & Yes & Yes \\
\hline $\begin{array}{l}\text { Wooldridge's score test, } \\
\text { chi2(2) }\end{array}$ & - & - & - & - & - & $16.55^{* * *}$ \\
\hline $\begin{array}{l}\text { Regression-based test } \\
\mathrm{F}(2,12587)\end{array}$ & - & - & - & - & - & $8.29 * * *$ \\
\hline $\mathrm{R}^{2} /$ pseudo $\mathrm{R}^{2}$ & 0.01 & 0.11 & 0.24 & 0.20 & 0.22 & 0.14 \\
\hline $\mathrm{N}$ & 15600 & 15600 & 15600 & 15600 & 15600 & 12641 \\
\hline
\end{tabular}

Notes: Robust t-statistics in parentheses; ${ }^{*}<0.10,{ }^{* *} \mathrm{p}<0.05,{ }^{* * *} \mathrm{p}<0.01$; LPM - linear probability model; for the probit model, the average partial effects are reported. 
more, the results show that SMEs which introduce new goods and services and SMEs with international quality certificates and foreign capital are more prone to export. All these results accord with the initial hypothesis. However, there is also a result which is not in line with the initial expectation. The coefficient of human capital suggests that SMEs which employ more educated labour are less probable to export than SMEs with less educated employees; however, its magnitude is almost zero (Column 2, Table 4). As the following step, I add industry and country dummies to the second specification to account for industry- and country-specific time-invariant factors and year dummies to capture the effect of time-varying factors which affect all SMEs in particular years. Column 3 reports the estimation results of the extended regression. The coefficient of the medium-term financial constraint variable became statistically insignificant at the conventional levels. This result shows that after controlling for industry-, country-, and period-specific factors, the medium-term financial constraints produce no significant effect on the likelihood of export participation of SMEs. The inclusion of country, industry, and period dummies also affects the significance levels and magnitudes of firm-specific control variables. For example, the coefficient of age becomes statistically insignificant; the coefficient of human capital becomes positive; the coefficient of employment increases; the coefficients of labour productivity, international quality certificate, and innovation remain statistically significant but decline in magnitude.

However, the inclusion of country variables can create a serious problem in econometric analysis as country dummies can absorb the cross-country variance related to certain independent variables and this can result in the insignificance of the coefficients of these variables even if they have an effect (Kittel - Obinger 2003; Busemeyer 2007; Sakamoto 2008). When instead of country dummies I include variables which measure country-specific characteristics such as ethnicity, language, and religion fragmentation, the coefficient of the medium-term financial constraint variable becomes negative and statistically significant, and its magnitude is equal to that reported in Column 2 (Column 4, Table 4). This shows that in the previous regression, the effects related to the medium-term financial constraint variable are mistakenly captured by the country dummies. In the following regressions, I use ethnicity, language, and religion variables as substitutes for country dummies.

The estimates presented in Columns 1-4 of Table 4 are obtained using the OLS estimator as the linear probability models are easy to estimate and interpret. However, the linear probability model has a few shortcomings. The most serious complication is that it is difficult to ensure that the linear probability model produces predictions falling into the $0-1$ range. For this reason, it is proposed to use either the probit or logit models because they constrain the model prediction 
to the $0-1$ interval. To check the sensitivity of the results to the choice of the functional form, the specification of the fourth column is re-estimated using the probit model. The estimated average partial effects show that the main results are robust to the choice of the functional form (Column 5, Table 4). In the probit model similar to the linear probability model, the average partial effect of the medium-term financial constraints on the probability is -0.02 and statistically significant. In regards of the firm-specific control variables, the average partial effects are equal to the OLS estimates for labour productivity, employment, age, human capital, innovation, and foreign ownership. For international quality certification, the average partial effect is smaller.

While the regression in the fourth column contains a set of control variables, there is still a possibility that there are some omitted factors which can affect not only the export participation but also the financial conditions of SMEs and therefore the estimation results can be potentially biased. There also exists empirical evidence for the reverse causal relationship between the financial constraints and probability of exporting, that is, financial circumstances of firms do not affect their exports but, instead, the export status of firms affects their financial health (Greenaway et al. 2007). To deal with these challenges, I instrument the mediumterm financial constraint variable with the economic sector - country - region average firm perception about the obstacles created by the access to finance. Furthermore, it is well known that non-instrumenting the labour productivity can also result in the biased results as it is a complex indicator affected by numerous factors. As an instrument for labour productivity, I use the labour productivity of a three-year lag. The conducted Wooldridge's score and regression-based endogeneity tests reject the null hypothesis that the variables of interest are exogenous (Column 6, Table 4). The coefficient of the medium-term financial constraint variable remains statistically significant and increases considerably. Now it appears that the SMEs, which are financially constrained in the medium-term, are $25 \%$ less likely to export. The coefficient of the labour productivity remains significant but decreases marginally. For all other control variables, the 2SLS estimator produces the results almost identical to those produced by the OLS estimator. To take into account the endogeneity problem, I consider the 2SLS results as the main ones.

The regression analysis conducted to examine the impact of the medium-term financial constraints is replicated to study the effect of the short-term financial constraints. Table 5 reports the estimation results together with heteroscedasticityconsistent t statistics. From Column 1, one can see that without controlling for any other factors, the short-term financial constraint variable has a significantly negative coefficient. Numerically, the short-term financially constrained SMEs are $8 \%$ less likely to export. However, as more control variables are added into 
the regression, the magnitude of the coefficient and its significance level fall. Column 3 shows that when one controls for firm-specific factors and includes country, industry, and period dummies, the short-term financial constraints appear to be statistically insignificant at the conventional levels. Following the experience with the medium-term financial constraint analysis, I include ethnicity, language, and religion variables instead of country dummies to account for timeinvariant national characteristics. The results of the new regression are reported in Column 4 of Table 5. The short-term financial constraint variable now has a negative and statistically significant coefficient of 0.02 , which is four times smaller than in the case of no controls. The magnitudes of the control variables are very close to those obtained from the analysis of the effects of the mediumterm financial constraints.

I also report the results of the probit model to check the sensitivity of the output to a choice of the model. As we can see, the average partial effects of the probit model have magnitudes and significance levels close to those of the linear probability model (Column 5, Table 5). In the analysis of the medium-term financial constraints, it is found that there is a significant endogeneity problem. To test the robustness of the results to endogeneity, I instrument the short-term financial constraint and labour productivity variables respectively with the economic sector - country - region average firm perception about the obstacles created by the access to finance and labour productivity with three-year lag. The conducted Wooldridge's score and regression-based endogeneity tests confirm the concern that these variables are endogenous (Column 6, Table 5). The estimation results show that the short-term financial constraint and control variables remain significant and their signs experience no change; however, the magnitudes of the coefficients of some of them change. Now it turns out that the presence of the short-term financial constraints reduces the probability of exporting by $25 \%$, which is equal to the effect produced by the medium-term financial constraints. The equal size of the coefficients of both types of financial constraints implies that for SMEs in their decisions to export, the access to short-term financing has the same importance as the access to medium financing. Thus, it appears that due to relatively relaxed accessibility, SMEs consider short-term financing as a substitute for medium-term financing, largely ignoring the matching principle. The coefficients of some firm-specific control variables change marginally, while the coefficients of the ethnicity and language fragmentation variables have relatively sizable changes in magnitudes. 
Table 5. Short-term financial constraints and export participation (Dependent variable: $\operatorname{Pr}[$ export participation = 1])

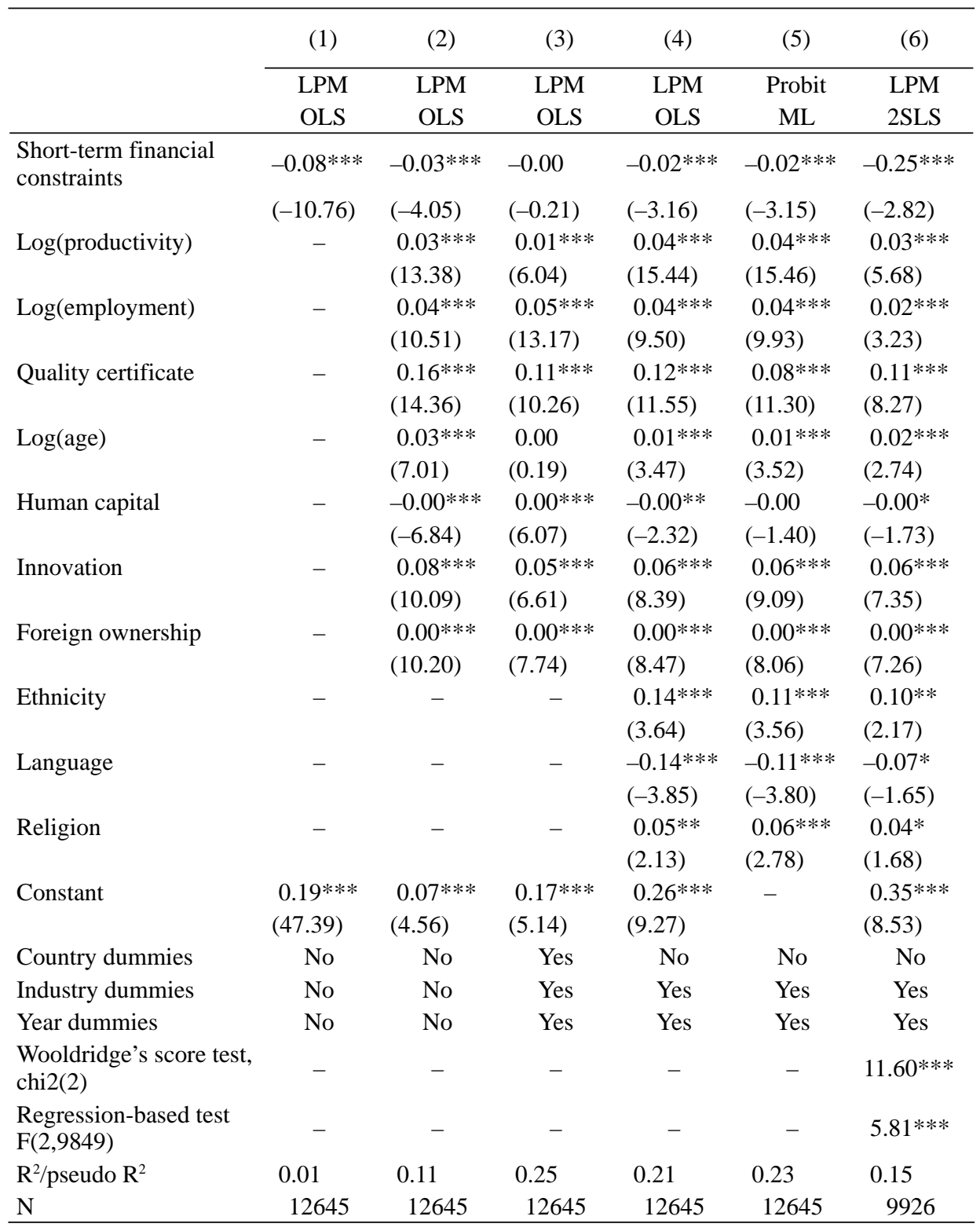

Notes: Robust t-statistics in parentheses; ${ }^{*} \mathrm{p}<0.10{ }^{* *} \mathrm{p}<0.05$, *** $\mathrm{p}<0.01$; LPM - linear probability model; for the probit model, the average partial effects are reported. 


\section{Further robustness checks}

In defining SMEs, I used the conventional definition. To check the sensitivity of the results to the definition of SMEs, I re-estimate the main regressions both for the medium- and short-term financial constraints using two alternative definitions. First, I define SMEs as firms with the number of employees less than 50 people, and then as firms with the number of employees less than 20 people. The corresponding estimation results, which are available upon request, show that the coefficients and significance levels of medium- and short-term constraint variables and those of controls experienced only marginal changes which do not produce a significant effect on the previous inferences.

Another concern can be that foreign ownership can potentially absorb the effect of financial constraints because it can play a role of proxy for access to finance as firms fully or partially owned by foreigners usually have better access to finance (Mertzanis 2016). To check this possibility, I rerun the main regressions for medium- and short-term financial constraints without the foreign ownership variable. The results, which are available upon request, show that the inclusion of the foreign ownership variables has only a marginal absorbing effect which does not affect the baseline inferences.

The other issue raising a concern is non-instrumenting innovation variable which can be a source of endogeneity problem as technology and export decisions can be interrelated to a certain extent (Aw et al. 2011). To test whether the potential endogeneity problem caused by the presence of innovation in the regressions affects the base inferences, I re-estimate the main regression without the innovation variable. The results, which are available upon request, demonstrate that the coefficients of the medium- and short-term financial constraints decline; however, the magnitudes of the declines are not large enough to change the previous inferences.

\section{Export status and financial constraints}

The previous analysis assumes that the financial constraints have an equal effect both on SMEs which export their products for the first time and on SMEs which have some exporting experience. However, there exists evidence that financial constraints affect mostly firms entering foreign markets for the first time because the first-time exporters have to cover the large entry-sunk costs, which can demand external financing, while firms just continuing exporting need to cover the fixed costs, which are substantially smaller than the entry-sunk costs, and therefore, these firms are less affected by financial constraints (Berman Héricourt 2010; Bellone et al. 2010). Using this logic, one can hypothesize that 
the medium-term financial constraints must be significantly more important for the first-time exporters because the sunk-entry costs are usually large amounts and not recovered in the short-term and therefore can be financed mainly through medium-term credits, while continuing exporters do not need to incur large sunk costs and hence can continue exporting even if they have limited access to medium-term finance. Regarding the short-term financial constraints, one believes that they can be equally important for first-time exporters as well as for continuous exporters because both categories need short-term financing to cover fixed costs and to meet the needs of greater working capital.

To address this point, I rerun regressions 4-6 of Table 4 and Table 5 for the sub-sample of the first-time exporters with non-exporters and the sub-sample of continuous exporters with non-exporters. The results show that the medium- and short-term financial constraints have no significant influence on the exporting decisions of the first-time exporters ${ }^{2}$. However, both kinds of constraints have a significant effect on the export participation of the continuous exporters. The coefficients of the medium- and short-term financial constraints for the continuous exporters are very close to the baseline results. This finding suggests that in the post-communist countries, the financial constraints prove no obstacle for SMEs starting to export but become a serious obstacle for SMEs continuing to export.

\section{Export mode and financial constraints}

The effect of financial constraints on the probability of exporting can differ not only by export status but also by export mode. Firms can bear sunk-entry, fixed, and other export-related costs and deliver their products directly to their foreign consumers, or alternatively, they can export their products indirectly through trade intermediaries by paying an additional per unit service fee (Abel-Koch 2013; Akerman 2018). Intermediary service fees are usually much smaller than costs firms incur if they decide to penetrate foreign markets themselves (Ahn et al. 2011); therefore, firms with insufficient internal financing or limited access to external financing choose to export indirectly. In this respect, one can expect that the medium-term financial constraints have a significant effect on the probability of exporting of direct exporters as they have to bear significant sunk costs. The short-term financial constraints are expected to be equally important for both direct and indirect exporters as they both may need short-term financing to meet the needs of the greater production. Although the use of trade intermediaries to export can help save on sunk-entry and fixed costs, it results in lower export

The results are not reported here for space limitation but available directly from the author upon request. 
revenues due to imperfectly enforceable contracts between indirect exporters and trade mediators (Abel-Koch 2013). Therefore, firms with sufficient financial liquidity and/or access to external financing tend to pay sunk-entry and fixed costs to directly export their products.

The consideration of the export mode factor requires separate analysis for the sub-samples of the direct and indirect exporters. Since the majority of exporting firms in the sample ship their products abroad directly as well as via trade intermediaries, it is important to select the threshold value of the share of direct exports beyond which a SME can be considered as a direct exporter. As the threshold value, I use the median value of the share of direct exports, which is $30 \%$. The regression results show that although the effects of both medium- and short-term financial constraints are statistically significant both for direct and indirect exporters, the effects are larger for indirect exporters ${ }^{3}$. Thus, the sunken entry costs for direct exporters are not so binding that the financial constraints can hinder direct entry to foreign markets. The larger effects of financial constraint for indirect exporters imply that despite the fact that even though indirect exporters do not pay sunk-entry costs, they have to incur other costs (marking export products, adapting to foreign standards, extending production facilities), which without access to external financing can be binding.

Additionally, to check the robustness of the results to the choice of the threshold value of the share of exports, I rerun the regressions for the threshold values of $50 \%$ and $80 \%$. The results show that the effects of the medium- and shortterm financial constraints are also larger for indirect rather than direct exporters. Finally, I also investigate whether the results differ across first-time and continuous direct and indirect exporters. Logically, one can suppose that the financial constraints should have a larger effect on the first-time direct exporters than on the other categories of exporters because they are supposed to incur larger sunkentry costs than the others. The regression results show that in fact, the financial constraints appear to be binding only for continuous direct and indirect exporters, with the larger effect for the latter.

\section{Heterogeneity analysis}

The above analysis assumes that the financial constraint and the control variables have the same effect on the probability of exporting for all post-communist countries and industry types, in all periods, and for all SMEs regardless of their

3 The results of regression specifications 4-6 of Tables 4-5 run for the subsample of direct exporters with non-exporters and the subsample of indirect exporters with non-exporters are not reported here because of space constraints. They are available from the author upon request. 
productivity, size, innovativeness, age, and ownership type although it is not necessary to be so. Therefore, I rerun Column 4-6 specifications of Tables 4-5 separately for sub-samples structured according to the regional origin, industry type, survey round, level of productivity, size, degree of innovativeness, age, and ownership type. Table 6 reports the coefficients and corresponding heteroscedasticityrobust t-statistics of the medium- and short-term financial constraint variables. Depending on the appropriateness of the model, the coefficients can represent the estimation results of either the linear probability model estimated by the OLS estimator or the probit model or the linear probability model estimated by the 2SLS estimator.

The region-based regressions, which to a certain extent reflect heterogeneity in financial development, can also help to test the hypothesis that financial constraints matter most for firms operating in countries with developed financial systems because in financially less developed countries, many firms are less likely to gain external funding even if they can pledge sufficient collateral simply because financial resources are limited (Berman - Héricourt 2010). In the same vein, one can expect that the medium-term financial constraints have a larger effect on the probability of exporting than the short-term ones in the countries with developed financial systems because they tend to have more capability to generate mediumterm financing than in the countries with less developed financial systems. In the context of the current country grouping, using the ratio of domestic credit to GDP ratio as a proxy for financial development, one can suggest that the new EU member states are countries with financial systems of relatively high maturity, the Balkans and the European part of CIS countries represent the financial systems of medium maturity, and the Caucasus and Central Asia are country groups with financial systems of low maturity.

The results suggest that the medium-term financial constraints have a significant effect on the probability of export participation of SMEs in the Caucasus and the new EU member states (Table 6). However, the effect is substantially larger for SMEs in the new EU countries than for the Caucasus SMEs. Quantitatively, the presence of medium-term financial constraints reduces the probability of exporting of SMEs in the new EU members by $57 \%$ and in Caucasus only by $2 \%$. Further, one can see that the short-term financial constraints are of importance only to SMEs in the new EU countries and Central Asia. In the EU, the short-term financial constraints reduce the probability of exporting by 57\%, while in Central Asia, the short-term constrains instead increase the probability of exporting albeit marginally, which is a surprising finding. In other words, the SMEs in Central Asia see exporting as an opportunity to solve their short-term liquidity problems. The larger magnitudes of the effects for SMEs in the new EU member states can indirectly indicate the importance of financial development in explaining the 
significance of the effects of financial constraint on the likelihood of exporting. Nevertheless, there is no evidence that the medium-term financial constraints produce a larger effect on the probability of exporting than the short-term financial constraints in the countries with more developed financial systems.

The effect of financial constraints on the likelihood of exporting can also differ across industries. For example, the export participation of firms from the capitalintensive (high sunk cost) industries can be more dependent on the availability of external finance than the export participation of firms from the labour-intensive (low sunk cost) industries (Stiebale 2011). Using the same logic, one can suggest that the medium-term financial constraints have a larger influence on the probability of exporting of the capital-intensive industries than the short-term financial constraints as capital investments are hardly recoverable in the shortterm. Table 6 reports the regression results for the industry types. It is found that the medium-term financial constraints have a significantly negative effect on the probability of exporting of SMEs operating in the food and tobacco products, textiles, garments, and leather, non-metallic mineral products, metals, and metal products, and wholesale and retail industries. The short-term financial constraint variable, in turn, produces a significantly negative effect on the likelihood of foreign market entry of the SMEs from the food and tobacco products, textiles,

Table 6. Heterogeneity in the effects of medium- and short-term financial constraints (Dependent variable: $\operatorname{Pr}[$ export participation $=1]$ )

\begin{tabular}{|c|c|c|}
\hline & $\begin{array}{c}\text { Medium-term financial } \\
\text { constraints }\end{array}$ & $\begin{array}{l}\text { Short-term financial } \\
\text { constraints }\end{array}$ \\
\hline \multicolumn{3}{|l|}{ Region } \\
\hline Balkans & $0.01(0.76)^{\mathrm{Ols}}$ & $0.01(0.32)^{\mathrm{OLS}}$ \\
\hline CIS-Caucasus & $-0.02 *(-1.86)^{\mathrm{Ols}}$ & $-0.02(-1.52)^{\mathrm{oLS}}$ \\
\hline CIS-Central Asia & $0.01(1.30)^{\text {Ols }}$ & $0.02 *(1.96)^{\mathrm{oLS}}$ \\
\hline CIS-Europe & $0.00(0.04)^{\mathrm{Ols}}$ & $-0.01(-0.69)^{\text {OLS }}$ \\
\hline New EU members & $-0.57 * * *(-2.85)^{2 \mathrm{sls}}$ & $-0.57 * *(-2.07)^{2 S L S}$ \\
\hline \multicolumn{3}{|l|}{ Industry type } \\
\hline Food and tobacco products & $-0.04 * *(-2.28)^{\mathrm{Ols}}$ & $-0.06 * * *(-2.66)^{\mathrm{OLS}}$ \\
\hline Textiles, garments, and leather & $-0.66 * * *(-2.69)^{2 \mathrm{sls}}$ & $-0.90 * *(-2.35)^{2 \text { SLS }}$ \\
\hline Wood, paper, and paper products & $-0.07(-1.12)^{\mathrm{Ols}}$ & $-0.13^{*}(-1.92)^{\mathrm{OLS}}$ \\
\hline $\begin{array}{l}\text { Coke, refined petroleum, } \\
\text { chemicals, plastics, } \\
\text { and rubber }\end{array}$ & $-0.03(-0.74)^{\mathrm{Ols}}$ & $-0.06(-1.42)^{\text {oLS }}$ \\
\hline $\begin{array}{l}\text { Non-metallic mineral products, } \\
\text { metals, } \\
\text { and metal products }\end{array}$ & $-0.60 *(-1.90)^{2 \mathrm{sls}}$ & $0.01(0.44)^{\text {oLS }}$ \\
\hline $\begin{array}{l}\text { Machinery, equipment, } \\
\text { electronics, transport means }\end{array}$ & $-0.00(-0.15)^{\mathrm{Ols}}$ & $-0.02(-0.49)^{\mathrm{OLS}}$ \\
\hline
\end{tabular}


Table 6. continued

\begin{tabular}{|c|c|c|}
\hline & $\begin{array}{l}\text { Medium-term financial } \\
\text { constraints }\end{array}$ & $\begin{array}{l}\text { Short-term financial } \\
\text { constraints }\end{array}$ \\
\hline Construction & $-0.01(-0.68)^{\mathrm{OLS}}$ & $-0.01(-1.06)^{\text {OLS }}$ \\
\hline Wholesale and retail & $-0.29 * * *(-2.94)^{2 \mathrm{SLS}}$ & $-0.21 *(-1.77)^{2 \mathrm{SLS}}$ \\
\hline Hotel and restaurants & $-0.01(-0.68)^{\text {OLS }}$ & $-0.01(-0.38)^{\mathrm{OLS}}$ \\
\hline Transport and IT & $0.01(0.20)^{\text {oLS }}$ & $-0.01(-0.32)^{\text {oLS }}$ \\
\hline \multicolumn{3}{|l|}{ Survey round } \\
\hline BEEPS III & $-0.02(-1.02)^{\text {OLS }}$ & - \\
\hline BEEPS IV & $-0.38 * * *(-2.83)^{2 \mathrm{SLS}}$ & $-0.47 * *(-2.48)^{2 S L S}$ \\
\hline BEEPS V & $-0.01 *(-1.72)^{\mathrm{OLS}}$ & $-0.02 * *(-2.02)^{\mathrm{OLS}}$ \\
\hline \multicolumn{3}{|l|}{ Productivity } \\
\hline Low & $-0.01(-0.98)^{\mathrm{OLS}}$ & $-0.33 * *(-1.96)^{2 S L S}$ \\
\hline Medium & $-0.21 * *(-2.42)^{2 S L S}$ & $-0.02^{* *}(-2.37)^{\mathrm{OLS}}$ \\
\hline High & $-0.56 * * *(-3.34)^{2 S L S}$ & $-0.51 * *(-2.05)^{2 S L S}$ \\
\hline \multicolumn{3}{|l|}{ Size } \\
\hline Small & $-0.26 * * *(-3.65)^{2 S L S}$ & $-0.23 * * *(-2.81)^{2 \mathrm{SLS}}$ \\
\hline Medium & $-0.01(-0.55)^{\text {OLS }}$ & $-0.00(-0.34)^{\mathrm{OLS}}$ \\
\hline \multicolumn{3}{|l|}{ Innovativeness } \\
\hline Innovative & $-0.42 * * *(-3.00)^{2 \mathrm{SLS}}$ & $-0.63 * *(-2.42)^{2 S L S}$ \\
\hline Non-innovative & $-0.25 * * *(-3.14)^{2 \mathrm{SLS}}$ & $-0.20 * *(-2.11)^{2 \mathrm{SLS}}$ \\
\hline \multicolumn{3}{|l|}{ Age } \\
\hline Young & $-0.17 *(1.95)^{2 S L S}$ & $-0.13(-1.23)^{2 S L S}$ \\
\hline Old & $-0.28 * * *(-2.66)^{2 \mathrm{SLS}}$ & $-0.32 * *(-2.15)^{2 S L S}$ \\
\hline \multicolumn{3}{|l|}{ Ownership } \\
\hline Foreign/Joint venture & $0.02(0.59)^{\mathrm{OLS}}$ & $-0.01(-0.32)^{\mathrm{OLS}}$ \\
\hline Domestic & $-0.25 * * *(-3.60)^{2 \mathrm{SLS}}$ & $-0.27 * * *(-2.94)^{2 \mathrm{SLS}}$ \\
\hline
\end{tabular}

Notes: Columns report the OLS/2SLS estimates of the effects of the medium- and short-term financial constraints on the probability of exporting with robust t-statistics in parentheses. All regressions include productivity, employment, quality certificate, age, human capital, innovation, ownership, ethnicity, language, religion, industry dummies, and period dummies as controls. The results are robust to the functional form of the model. ${ }^{*} \mathrm{p}<0.10,{ }^{* *} \mathrm{p}<0.05,{ }^{* * *} \mathrm{p}<0.01$.

garments, and leather, wood, paper and paper products, and wholesale and retail industries. As the aforementioned industries represent low sunk cost industries, these findings do not confirm the point that the availability of external finance has a larger impact on the probability of exporting of firms from high sunk cost industries than on the likelihood of exporting of firms from low sunk cost industries, at least in the post-communist countries.

The coefficient estimates can also vary over time due to period-specific circumstances, for example, financial crisis; therefore, as the following step, I run a separate regression for each round of the BEEPS. Table 6 reports the corresponding estimation results which show that the medium- and short-term financial con- 
straints have a significant effect on the probability of exporting in the fourth and fifth rounds. The magnitudes of the coefficients show that in fact, in the fourth round, the financial constraints have a larger influence on export participation than in the fifth round. This result is not surprising as the fourth round of BEEPs falls into the 2008-2009 crisis and can indicate that for SMEs, the availability of external funds, especially short-term financing, appears to be more important during crisis periods when there are usually larger declines in retained earnings and longer delays in payments.

Further, I examine whether the impact of financial constraints varies across subgroups of firms with differences in productivity levels. Access to finance, for example, can be of importance only for the export participation of high productive firms (Berman - Héricourt 2010). The intuition is that the high productive firms are more likely to decide to enter foreign markets as they have a higher chance of being successful and therefore for them, access to external finance can be a decisive factor. Analogously, one can suppose that the medium-term financing can be of greater importance for high productive SMEs than for medium and low productive SMEs as the former are more likely to export and therefore more likely need medium-term financing to fund the sunk-entry costs. Table 6 presents the estimated coefficients of the medium- and short-term financial constraint variables for three sub-samples arranged according to the productivity levels. Low productivity SMEs are entities whose productivity falls into the first quartile of the distribution, medium productivity SMEs are entities whose productivity is in the second and third quartiles, and high productivity SMEs are entities whose productivity falls into the last quartile. The results show that the medium-term financial constraints produce a significant effect on the likelihood of exporting of medium and high productive SMEs. As expected, the magnitudes of the effects indicate the larger importance of the medium-term financial constraints for high productive SMEs than for their medium productive counterparts. The short-term financial constraints are found to have a significantly negative effect on exporting probability of SMEs of all productivity categories. The magnitudes of the effects again are larger for high productive SMEs than for other productivity category SMEs. However, interestingly, the short-term financial constraints have a considerably larger magnitude for the low productivity SMEs than for the medium productivity ones. This finding suggests that low productivity firms find it difficult to access medium-term funding to finance sunk and other costs related to export operations due to higher requirements demanded by creditors, so they opt to short-term funds, which tend to be easier to access, as a substitute. So, the postcommunist data do not provide uniform support for the hypothesis that access to finance must be critical mainly for the high productive enterprises. 
Firm size can also be an important factor determining the extent of sensitivity of the probability of export participation to financial constraints. Larger firms usually have larger capacity and more internal resources necessary for entry to foreign markets than smaller firms. Therefore, one can expect that the likelihood of exporting of bigger firms is less sensitive to financial constraints than that of smaller firms. To test the sensitivity of the results to firm sizes, I run separate regressions for medium and small SMEs. A firm is small if the number of its employees is less than 20, and a firm is medium if the number of employees is greater or equal to 20 but less than 100 . The regression results show that the medium- and short-term financial constraints have a significantly negative effect on the probability of exporting of small firms only, which confirms the initial hypothesis. The magnitudes of the coefficients demonstrate that for small firms, the availability of medium-term financing has a larger effect on the probability of exporting than the availability of short-term financing. This result accords with the headline hypothesis that the medium-term constraints should produce a greater effect on the likelihood of exporting as the sunk-entry costs usually cannot be recovered in the short-term.

Innovativeness of SMEs can also affect the significance and intensity of the effects of financial constraints on the export participation. In comparison with the likelihood of exporting of non-innovative firms, the likelihood of exporting of innovative firms is more likely to be dependent on the availability of external funds as innovative activities tend to absorb substantial financial resources. Table 6 reports the estimation results of regressions separately run for the subsamples of innovative and non-innovative SMEs. The medium- and short-term financial constraints have a significant influence on the probability of exporting of both innovative and non-innovative firms. The magnitudes of the coefficients confirm the hypothesis of the greater importance of the financial constraints for innovative SMEs than for non-innovative ones. The comparison of the magnitudes of the medium- to short-term financial constraints shows that in contrast to non-innovative SMEs, for innovative SMEs, the later produces a larger effect than the former. This result does not seem surprising because innovative firms due to better growth prospects usually have more agency conflicts which force them to draw on the short-term credit.

Age is another factor which can drive heterogeneity in the magnitudes and significance levels of the effects of financial constraints on the probability of exporting. Older firms, in contrast to younger firms, are more likely to consider foreign market penetration because they have longer marketing and organisation experiences necessary for successful entry and therefore their probability of exporting can be more dependent on external financing than the probability of younger firms. Following the general convention, I consider a firm to be young if its age 
is less than 10 and old if its age is 10 or greater. The regression results obtained for the sub-samples of young and old SMEs show that the medium-term financial constraints have an effect on the probability of exporting of SMEs from both age groups, albeit with larger and more significant magnitude for old SMEs than for young ones, and the short-term financial constraints have a significant influence only on old SMEs. These findings accord with the initial expectation. The insignificance of the short-term financial constraints for young firms can indicate that young firms tend to refrain from borrowing short-term to finance sunk costs, probably trying to avoid interest rate and refinancing risks. For old firms, the short-term financial constraints have greater importance for exporting than the medium-term financial constraints, probably due to lower interest rates and desire to preserve autonomy.

Finally, types of ownership can also influence the strength of the relationship between the likelihood of exporting and financial constraints. For foreign firms and joint ventures, financial constraints can have a less binding effect on the probability of exporting than for domestic firms because firms with foreign capital can use the resources of foreign partners to a great advantage in exporting. Table 6 shows the results of the regressions separately run for domestic SMEs and SMEs totally or partially owned by foreigners. Consistent with the hypothesis, the medium- and short-term financial constraints appear to have a significant effect only on the exporting probability of domestic SMEs. The short-term financial constraint variable has a larger magnitude than the medium-term constraint variable, indicating the importance of lower interest rates, less stringent collateral requirements, and retaining autonomy.

\section{CONCLUSIONS}

This paper analyses the impact of medium- and short-term financial constraints on the probability of export participation of SMEs in 28 post-communist countries. The cross-sectional analysis conducted over the sample, which combines data of the last three rounds of the BEEPS, shows that the medium- and shortterm financial constrains produce a significantly negative effect on the probability of exporting. Quantitatively, the presence of either medium- or short-term financial constraints reduces the likelihood of exporting by $25 \%$. So there is no empirical support for the proposition that the medium-term financial constraints produce a significantly larger effect on the probability of exporting than the shortterm ones. This finding suggests that probably due to easier accessibility, SMEs treat short-term financing equally with medium-term financing despite the maturity mismatch risks. The significance of the medium- and short-term financial 
constraint variables imply that sunk-entry costs, risks of delays in payments for goods shipped abroad, and difficulties in paying exporting costs can be barriers for SMEs willing to export. Further, the analysis reveals that the financial constraints do not create a significant obstacle for the first-time exporters but can be a problem for the continuous exporters. Besides, it is found that the financial constraints appear to be more binding for the indirect exporters rather than for the direct exporters.

The heterogeneity analysis conducted to examine whether the results differ across country groups, industry types, periods, and firm categories shows that there is certain heterogeneity in the significance levels and magnitudes of the effects of the medium- and short-term financial constraints. In particular, the financial constraints appear to be a significant factor for SMEs from the food and tobacco products, textiles, garments, and leather, wood, paper, and paper products, non-metallic mineral products, metals, and metal products, and wholesale and trade industries. Surprisingly, there is no evidence for the statistically significant relationship between the financial constraints and probability of exporting of SMEs from the high sunk cost machinery, equipment, electronics, and transport means industries. The comparison between the magnitudes of the medium-term financial constraints and those of the short-term financial constraints show that the later exerts a larger influence on the probability of export participation of SMEs from the low sunk cost industries than the former. Further, the analysis shows that both medium- and short-term financial constraints have a significantly larger effect on the likelihood of exporting in the third round conducted in the financial crisis than in the fourth round of the survey conducted in the post-crisis period. Finally, the regression results obtained from the sub-samples of different firm types show that the exporting probability of innovative, old, domestic, and small enterprises depends on the availability of external financing to a greater extent than correspondingly non-innovative, young, fully or partially foreign owned and medium-sized firms. The short-term financial constraints compared to the medium-term constraints produce a larger effect on the probability of exporting of low productivity, innovative, old, and domestic SMEs.

These findings have important policy implications for the post-communist economies. They suggest that it is critical to relax the medium- and short-term financial constraints as they have a large and significant influence on the exporting decisions of SMEs. For this purpose, the subsidization of loans and/or guaranteeing loans made by commercial banks for exporting activities of SMEs seem to be an appropriate policy option, especially for the continuous and indirect exporters and during financial distress. Furthermore, it is important to target high productive, innovative, old, and domestic SMEs as the financial constraints have a larger negative effect on the probability of exporting of these types of firms. However, 
one should understand that the provision of subsidies and loan guarantees does not solve the problem of credit rationing at heart but provides only a temporary alleviation. To solve the problem, it is necessary to address its cause, which is basically information asymmetry between lenders and borrowers driven by the lack of credible financial data on SMEs. In this regard, it can be useful to establish a credit risk database on SMEs like the one developed in Japan, which collects financial and other relevant data from SMEs and provides access of this data to lenders for performing reliable financial assessment of loan applications of SMEs (Kuwahara et al. 2015). The reduction of information asymmetry will also help to resolve difficulties of obtaining medium- and long-term credits and therefore will allow SMEs to follow the matching principle. Additionally, to stimulate export participation of SMEs, it is necessary through stimulus programs to encourage firms to upgrade the quality of the produced goods and services to the internationally accepted standards and motivate innovation activities. However, as with all subsidy, guarantee, and stimulus programs, policy makers need to be cautious not to create zombie exporting SMEs.

\section{REFERENCES}

Abel-Koch, J. (2013): Who Uses Intermediaries in International Trade? Evidence from Firm-level Survey Data. The World Economy, 36(8): 1041-1064.

Abor, J. - Agbloyor, E. - Kuipo, R. (2014): Bank Finance and Export Activities of Small and Medium Enterprises. Review of Development Finance, 4(2): 97-103.

Ahn, J. - Khandelwal, A. - Wei, S. (2011): The Role of Intermediaries in Facilitating Trade. Journal of International Economics, 84(1): 73-85.

Akerman, A. (2018): A Theory on the Role of Wholesalers in International Trade Based on Economies of Scope. Canadian Journal of Economics/Revue Canadienne d'économique, 51(1): 156185.

Alesina, A. - Devleeschauwer, A. - Easterly, W. - Kurlat, S. - Wacziarg, R. (2003): Fractionalization. Journal of Economic Growth, 8(2): 155-194.

Aw, B. - Roberts, M. - Xu, D. (2011): R\&D Investment, Exporting, and Productivity Dynamics. American Economic Review, 101(4): 1312-1344.

Bellone, F. - Musso, P. - Nesta, L. - Schiavo, S. (2010): Financial Constraints and Firm Export Behaviour. World Economy, 33(3): 347-373.

Berman, N. - Héricourt, J. (2010): Financial Factors and the Margins of Trade: Evidence from Cross-Country Firm-Level Data. Journal of Development Economics, 93(2): 206-217.

Busemeyer, M. (2007): Determinants of Public Education Spending in 21 OECD Democracies, 1980-2001. Journal of European Public Policy, 14(4): 582-610.

Chaney, Th. (2016): Liquidity Constrained Exporters. Journal of Economic Dynamics and Control, 72: 141-154.

Chittenden, F. - Hall, G. - Hutchinson, P. (1996): Small Firm Growth, Access to Capital Markets and Financial Structure: Review of Issues and an Empirical Investigation. Small Business Economics, 8(1): 59-67. 
De Maeseneire, W. - Claeys, T. (2012): SMEs, Foreign Direct Investment and Financial Constraints: The Case of Belgium. International Business Review, 21(3): 408-424.

Esperança, P. J. - Gama, M. A. - Gulamhussen, A. M. (2003): Corporate Debt Policy of Small Firms: An Empirical (Re)examination. Journal of Small Business and Enterprise Development, 10(1): 62-80.

Fauceglia, D. (2015): Credit Constraints, Firm Exports and Financial Development: Evidence from Developing Countries. The Quarterly Review of Economics and Finance, 55: 53-66.

Garcia-Teruel, P. - Martinez-Solano, P. (2007): Short-Term Debt in Spanish SMEs. International Small Business Journal, 25(6): 579-602.

Greenaway, D. - Guariglia, A. - Kneller, R. (2007): Financial Factors and Exporting Decisions. Journal of International Economics, 73(2): 377-395.

Jinjarak, Y. - Wignaraja, G. (2016): An Empirical Assessment of the Export - Financial Constraint Relationship: How Different are Small and Medium Enterprises? World Development, 79: 152163.

Kittel, B. - Obinger, H. (2003): Political Parties, Institutions, and the Dynamics of Social Expenditure in Times of Austerity. Journal of European Public Policy, 10(1): 20-45.

Kuwahara, S. - Yoshino, N. - Sagara, M. - Taghizadeh-Hesary, F. (2015): Role of the Credit Risk Database in Developing SMEs in Japan: Lessons for the Rest of Asia. ADBI Working Paper 547. Tokyo: Asian Development Bank Institute.

Li, Zh. - Yu, M. (2009): Exports, Productivity, and Credit Constraints: A Firm-Level Empirical Investigation of China, Global COE Hi-Stat. Discussion Paper Series gd09-098, Institute of Economic Research, Hitotsubashi University.

Manova, K. (2012): Credit Constraints, Heterogeneous Firms, and International Trade. The Review of Economic Studies, 80(2): 711-744.

Manova, K. - Wei, Sh. - Zhang, Zh. (2015): Firm Exports and Multinational Activity under Credit Constraints. Review of Economics and Statistics, 97(3): 574-588.

Melitz, M. J. (2003): The Impact of Trade on Intra-Industry Reallocations and Aggregate Industry Productivity. Econometrica, 71 (6): 1695-1725.

Mertzanis, C. (2016): Ownership Structure and Access to Finance in Developing Countries. Applied Economics, 49(32): 3195-3213.

Michaelas, N. - Chittenden, F. - Poutziouris, P. (1999): Financial Policy and Capital Structure Choice in U.K. SMEs: Empirical Evidence from Company Panel Data. Small Business Economics, 12(2): 113-130.

Minetti, R. - Zhu, S. C. (2011): Credit Constraints and Firm Export: Microeconomic Evidence from Italy. Journal of International Economics, 83(2): 109-125.

Nagaraj, P. (2014): Financial Constraints and Export Participation in India. International Economics, 140: 19-35.

Öhman, P. - Yazdanfar, D. (2017): Short- and Long-Term Debt Determinants in Swedish SMEs. Review of Accounting and Finance, 16(1): 106-124.

Sakamoto, T. (2008): Economic Policy and Performance in Industrial Democracies. London: Routledge.

Stiebale, J. (2011): Do Financial Constraints Matter for Foreign Market Entry? A Firm-Level Examination. The World Economy, 34(1): 123-153.

Verani, St. - Gross, T. (2012): Financing Constraints, Firm Dynamics, and International Trade, Finance and Economics. Discussion Series, No. 2012-68, Board of Governors of the Federal Reserve System (U.S.).

Viscione, J. (1986): How Long Should You Borrow Short Term? Harvard Business Review, (March-April). 